\title{
Kinetics of Azanone (HNO) Reactions with Thiols: Effect of pH
}

\author{
Renata Smulik-Izydorczyk ${ }^{1} \cdot$ Karolina Dębowska $^{1} \cdot$ Michał Rostkowski $^{1} \cdot$ Jan Adamus ${ }^{1} \cdot$ Radosław Michalski $^{1}$. \\ Adam Sikora $\mathbb{1}^{1}$
}

Accepted: 10 April 2021 / Published online: 5 May 2021

(c) The Author(s) 2021

\begin{abstract}
HNO (nitroxyl, IUPAC name azanone) is an electrophilic reactive nitrogen species of growing pharmacological and biological significance. Here, we present data on the $\mathrm{pH}$-dependent kinetics of azanone reactions with the low molecular thiols glutathione and $\mathrm{N}$-acetylcysteine, as well as with important serum proteins: bovine serum albumin and human serum albumin. The competition kinetics method used is based on two parallel HNO reactions: with $\mathbf{R S H} / \mathbf{R S}^{-}$or with $\mathbf{O}_{2}$. The results provide evidence that the reaction of azanone with the anionic form of thiols $\left(\mathbf{R S}^{-}\right)$is favored over reactions with the protonated form (RSH). The data are supported with quantum mechanical calculations. A comprehensive discussion of the HNO reaction with thiolates is provided.
\end{abstract}

Keywords Azanone $\cdot \mathrm{Nitroxyl} \cdot \mathrm{HNO} \cdot$ Thiols $\cdot$ Boronate probes

\section{Introduction}

HNO (nitroxyl, IUPAC name azanone) is the protonated product of the one-electron reduction of nitric oxide ( $\mathrm{NO}$ ). In contrast to ${ }^{-N O}$, azanone is a strong electrophile that is highly reactive toward various nucleophiles. It can also be oxidized to ${ }^{\circ} \mathrm{NO}[\boldsymbol{E}]^{\circ}\left({ }^{\circ} \mathrm{NO} / \mathrm{HNO}\right)=-0.14 \mathrm{~V}$ [1], recently revised as $\boldsymbol{E}^{\circ}(\mathbf{N O} / \mathbf{H N O})=0.27 \mathrm{~V}[2]$. HNO reacts with molecular oxygen, [3-9], nitric oxide [10], nitrite [11, 12], hydroxylamine [12, 13], sulfite [12], thiosulfate [12, 13], metalloproteins [14-18], metalloporphyrines [19-22], thiols [3, 13, 14, 23], C- and S-nitroso compounds [12, 24], nitroxides [13, 25-27] and phosphines [12, 13, 28-33]. Thiols constitute the main biological target of HNO [34]. The fast reaction between $\mathbf{H N O}$ and thiols $\left(\sim 10^{6} \mathrm{M}^{-1} \mathrm{~s}^{-1}\right.$ $[3,13,14])$ results in the formation of $N$-hydroxysulfenamide (Reaction 1), which in the presence of excess thiol is converted into the corresponding disulfide and hydroxylamine (Reaction 2). $N$-hydroxysulfenamide can also undergo spontaneous isomerization to sulfinamide (Reaction 3). It has been postulated that sulfinamides are

Adam Sikora

adam.sikora@p.lodz.pl

1 Institute of Applied Radiation Chemistry, Lodz University of Technology, Lodz, Poland unique products of the HNO reaction with thiols and might serve as in vivo biomarkers of azanone formation [34].

$$
\begin{aligned}
& \mathrm{HNO}+\mathrm{RS}^{-} \rightarrow \mathrm{RSNHO}^{-} \stackrel{\mathrm{H}^{+}}{\longrightarrow} \mathrm{RSNHOH} \\
& \mathrm{RSNHOH}+\mathrm{RSH} \rightarrow \mathrm{RSSR}+\mathrm{NH}_{2} \mathrm{OH} \\
& \mathrm{RSNHOH} \rightarrow \mathrm{RS}(\mathrm{O}) \mathrm{NH}_{2}
\end{aligned}
$$

The high reactivity of HNO toward thiols and their abundance in biological systems are major factors determining the short lifetime of azanone in vivo [34]. On the other hand, it has been proposed that azanone can be generated in several thiol-related pathways [35, 36]. The first is the reaction of thiols with S-nitrosothiols (Reaction 4) [37, 38]. Similar routes of HNO generation include RSNO reactions with $\mathbf{H}_{2} \mathbf{S}$ (Reaction 5 and/or Reactions 6-7) [39] or ascorbate anion (Asc' ${ }^{-}$) (Reactions 8-9) [40].

$$
\begin{aligned}
& \mathrm{RSNO}+\mathrm{R}^{\prime} \mathrm{SH} \rightarrow \mathrm{RSSR}^{\prime}+\mathrm{HNO} \\
& \mathrm{RSNO}+\mathrm{HS}^{-} \rightarrow \mathrm{RSS}^{-}+\mathrm{HNO} \\
& \mathrm{RSNO}+\mathrm{HS}^{-} \rightarrow \mathrm{RSH}+\mathrm{SNO}^{-} \\
& \mathrm{SNO}^{-}+\mathrm{HS}^{-}+\mathrm{H}^{+} \rightarrow \mathrm{HSS}^{-}+\mathrm{HNO}
\end{aligned}
$$




$$
\mathrm{RSNO}+\mathrm{Asc}^{-} \rightarrow \mathrm{RSH}+\mathrm{AscNO}^{-}
$$

$$
\mathrm{AscNO}^{-} \rightarrow \mathrm{DHA}+\mathrm{HNO}
$$

Doctorovich et al. demonstrated that azanone can also be formed during the reactions of ${ }^{\bullet} \mathbf{N O}$ with ascorbate or phenols (e.g., tyrosine, hydroquinone, salicylic acid, $\alpha$-tocopherol or acetaminophen), according to Reaction 10 $[41,42]$.

$$
\mathrm{NO}+\mathrm{ROH} \rightarrow \mathrm{RO}+\mathrm{HNO}
$$

Recently, it has been proposed that HNO is also produced in the reaction of thiols with nitric oxide [36]. ${ }^{\bullet} \mathbf{N O}$ is known to react with thiols, with the formation of $\mathbf{N}_{\mathbf{2}} \mathbf{O}$ and corresponding disulfides [43] and/or sulfenic acids [44]. However, both the mechanism [36, 43, 44] and the kinetics of these processes are elusive [36, 45-47]. The formation of HNO has also been linked to the mechanism describing the formation of dinitrosyl-iron complexes (DNIC) from ${ }^{\circ} \mathbf{N O}$, $\mathbf{R S}^{-}$and $\mathbf{F e}^{2+}$ [48-50]. DNIC are biologically relevant bioinorganic complexes of ${ }^{\boldsymbol{N}} \mathbf{N O}$, and perhaps the most abundant nitric oxide-derived adducts present in cells producing ${ }^{\bullet} \mathbf{N O}[51,52]$. It has been suggested that they can act as RSNO precursors [49, 50, 53] and HNO/NO ${ }^{-}$donors $[54,55]$. Due to the rapid scavenging of HNO by thiols, the generation of azanone is not expected to affect the DNICdependent RSNO formation. The number of these processes makes it challenging to formulate a proper description of the thiols/ ${ }^{\circ} \mathbf{N O} / \mathbf{H N O}$ interactome.

In the absence of scavengers, HNO is known to spontaneously dimerize with a second-order rate constant of $\sim 8 \times 10^{6} \mathrm{M}^{-1} \mathrm{~s}^{-1}$ [10]. The intermediate product of this reaction, hyponitrous acid, dehydrates to final decomposition products, nitrous oxide and water (Reaction 11).

$$
2 \mathrm{HNO} \rightarrow[\mathrm{HONNOH}] \rightarrow \mathrm{N}_{2} \mathrm{O}+\mathrm{H}_{2} \mathrm{O}
$$

The propensity of HNO to undergo the above reaction requires the use of donor molecules, the decomposition product of which is the HNO molecule. The most often studied and commonly used HNO donor is Angeli's salt, which decomposes at $25{ }^{\circ} \mathrm{C}$ with a rate constant of $6.8 \times 10^{-4} \mathrm{~s}^{-1}$ $\left(\mathrm{t}_{1 / 2} \sim 17 \mathrm{~min}\right)$ in a $\mathrm{pH}$ range from 4 to $8.6[56,57]$. The fact that its decomposition rate constant is independent of $\mathrm{pH}$ is a unique feature of Angeli's salt compared to other HNO donors. Other frequently used HNO donors are Piloty's acid and its derivatives [57-61]. Unsubstituted Piloty's acid ( $N$ hydroxybenzenesulfonamide) releases azanone favorably under alkaline conditions only, whereas Piloty's acid derivatives, substituted at different positions of the aromatic ring, release azanone across a wide range of $\mathrm{pH}$ values [57, 60, 61]. The rate constant of HNO release at a given $\mathrm{pH}$ depends on the ring substituents in Piloty's acid derivatives [60, 61].
Similarly to ${ }^{*}$ O, HNO exhibits unique pharmacological effects that have potential benefits for the treatment of a variety of diseases. Chronologically, the first described biological action of HNO was the inhibition of alcohol dehydrogenase by cyanamide (a pharmacological alcohol deterrent agent), via its catalase-dependent bioactivation into an HNO donor [62-64]. More recently, HNO donors have been proposed as agents for the treatment of heart failure [65-68]. Azanone donors have been shown to induce apoptosis, suppress tumor angiogenesis, and help to achieve analgesia [69-73]. Some of these effects could be connected to HNO reactions, mainly with cysteine residues of key enzymes responsible for the observed pharmacological effects. For instance, HNO generated from cyanamide modifies the cysteine-302 residue in aldehyde dehydrogenase, leading to irreversible inhibition of the enzyme [63]. The mechanism by which azanone affects the heart is a matter of intense research. It has been proposed that HNO donors enhance cardiac contractility, by targeting the regulatory protein phospholamban $[74,75]$. Keceli et al. found that HNO reacts with Cys-41 and Cys-46 via the formation of the intramolecular disulfide bond, which forces conformational changes in the protein and enhances cardiac function as a result [74].

In a previous study, we investigated the reactivity of HNO toward selected thiols: cysteine $\left(k_{C y s}=(4.5 \pm 0.9) \times\right.$ $\left.10^{6} \mathrm{M}^{-1} \mathrm{~s}^{-1}, \mathrm{p} K_{\mathrm{a}}=8.3\right)$, glutathione $\left(k_{G S H}=(3.1 \pm 0.6) \times\right.$ $\left.10^{6} \mathrm{M}^{-1} \mathrm{~s}^{-1}, \quad \mathrm{p} K_{\mathrm{a}}=8.8\right), \quad N$-acetylcysteine $\left(k_{N A C}=(1.4 \pm\right.$ $\left.0.3) \times 10^{6} \mathrm{M}^{-1} \mathrm{~s}^{-1}, \mathrm{p} K_{\mathrm{a}}=9.5\right)$ and captopril $\left(k_{C a p}=(6 \pm\right.$ 1) $\left.\times 10^{5} \mathrm{M}^{-1} \mathrm{~s}^{-1}, \mathrm{p} K_{\mathrm{a}}=9.8\right)$. We found that at $\mathrm{pH} 7.4$ the rate constant of the HNO reaction with thiol depends on its -SH group $\mathrm{p} K_{\mathrm{a}}$. [3] In the present study, we explored the dependence of the rate constants of the reactions of HNO with selected biologically important thiols on $\mathrm{pH}$. The data show the effect of $\mathrm{pH}$ on HNO reactivity toward the low molecular thiols $\mathrm{N}$-acetylcysteine and glutathione and the thiol proteins bovine and human serum albumins.

\section{Materials and Methods}

\section{Materials}

Angeli's salt (AS, Sodium Trioxodinitrate, $\mathbf{N a}_{2} \mathbf{N}_{\mathbf{2}} \mathbf{O}_{\mathbf{3}}$ ) was synthesized according to a published procedure [57]. Stable solutions of Angeli's salt prepared in $1 \mathrm{mM} \mathrm{NaOH}(\mathrm{pH}$ 11) were stored on ice during the experiments and each day a fresh $\mathbf{A S}$ stock solution was prepared [56, 57]. A boronate probe, coumarin boronic acid (CBA), which enables the detection of peroxynitrite $\left(\mathbf{O N O O}^{-}\right)$formed in the reaction of HNO with molecular oxygen, was synthesized according to a published procedure [76]. All thiols (glutathione (GSH), $N$-acetylcysteine (NAC), bovine serum 


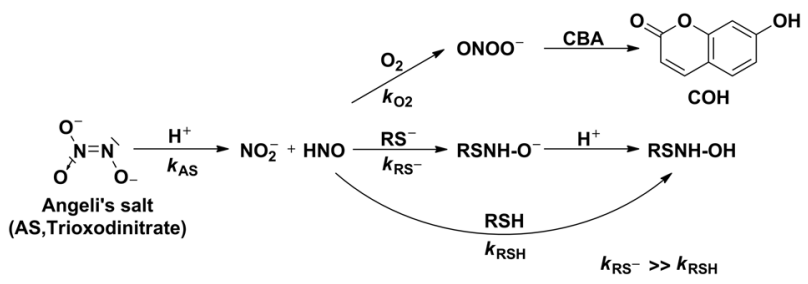

Scheme 1 The reaction model used to determine the rate constants of the reactions of HNO with $\mathbf{R S H} / \mathbf{R S}$

albumin (BSA) and human serum albumin (HSA)), as well as all other chemicals (of the highest purity available) were purchased from Sigma-Aldrich Corp. By varying the amounts of salts (monobasic dihydrogen phosphate and dibasic monohydrogen phosphate) a range of buffers between $\mathrm{pH} 6.4$ and 8.3 were prepared. All solutions were prepared using deionized water (Millipore Milli-Q system).

\section{Competition Kinetic Method}

The competition kinetic method used in this study followed the procedure described previously [3, 12]. Angeli's salt, the most common HNO donor, was used. Azanone released from Angeli's salt reacts either with a corresponding thiol (RSH and $\mathbf{R S}^{-}$) or with molecular oxygen (Scheme 1). The latter, relatively fast reaction $\left(k=(1.8 \pm 0.3) \times 10^{4} \mathrm{M}^{-1} \mathrm{~s}^{-1}\right) \quad$ [3] results in the formation of peroxynitrite, which can be easily detected fluorometrically with the use of the fluorogenic probe, coumarin boronic acid (CBA). Across the whole studied $\mathrm{pH}$ range, $\mathbf{C B A}$ reacts rapidly and directly with $\mathbf{O N O O}^{-}$ $\left(k=7.3 \times 10^{5} \mathrm{M}^{-1} \mathrm{~s}^{-1}, \mathrm{pH} 6.6 ; k=1 \times 10^{6} \mathrm{M}^{-1} \mathrm{~s}^{-1}, \mathrm{pH} 7.4 ;\right.$ $k=4.5 \times 10^{5} \mathrm{M}^{-1} \mathrm{~s}^{-1}, \mathrm{pH} 8.2$ ), with the formation of blue fluorescent 7-hydroxycoumarin $(\mathbf{C O H})$ as the main product $[3,76]$. The ratio of initial rates of $\mathbf{C O H}$ formation in the absence and presence of scavenger $\mathrm{S}$ can be expressed by the equation

$\frac{v_{0}}{v_{\mathrm{i}}}=1+\frac{k_{\mathrm{obs}}[\mathrm{S}]_{\mathrm{i}}}{k_{\mathrm{O} 2}\left[\mathrm{O}_{2}\right]}$

where $\boldsymbol{k}_{\mathbf{o b s}}$ and $\boldsymbol{k}_{\mathbf{O}_{2}}$ are the second order rate constants of HNO reactions with the scavenger (thiol/thiolate) and molecular oxygen, respectively, and $[\mathrm{S}]$ and $\left[\mathrm{O}_{2}\right]$ denote the total concentrations of thiol $\left([\mathbf{S}]=[\mathbf{R S H}]+\left[\mathbf{R S}^{-}\right]\right)$and molecular oxygen. In solutions remaining in equilibrium with air the concentration of molecular oxygen is equal to $225 \mu \mathrm{M}$ [77]. Based on Eq. (1), the $\boldsymbol{k}_{\mathbf{o b s}} / \boldsymbol{k}_{\mathbf{O}_{2}}$ ratio was determined for each $\mathrm{pH}$ value. Figure 1 illustrates the used method to determine the $\boldsymbol{k}_{\mathbf{o b s}} / \boldsymbol{k}_{\mathbf{O}_{2}}$ ratio at $\mathrm{pH}$ 6.5.

\section{Stopped-flow Measurements}

Angeli's salt $(6 \mu \mathrm{M}$ in $1 \mathrm{mM} \mathrm{NaOH})$ was mixed rapidly with a solution containing the coumarin based monoborate probe

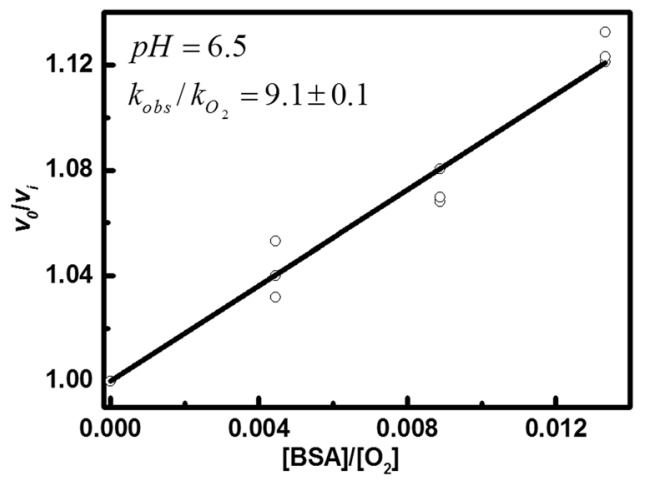

Fig. 1 The $v_{0} / v_{\mathrm{i}}$ ratio as a function of $[\mathbf{B S A}] /\left[\mathbf{O}_{2}\right]$ at $\mathrm{pH}=6.5$

CBA $(50 \mu \mathrm{M})$, phosphate buffer $(50 \mathrm{mM}$, pH range 6.4-8.3), metal chelator dtpa $(100 \mu \mathrm{M}), 10 \% \mathbf{C H}_{3} \mathbf{C N}$ and the corresponding thiol compound at the appropriate concentration. Glutathione and $\mathrm{N}$-acetylcysteine were used in a concentration range from 1 to $3 \mu \mathrm{M}$. Human or bovine serum albumin were used in the concentration range from 2 to $6 \mu \mathrm{M}$. Both reaction mixtures - the alkaline solution of the HNO donor and the solution of the corresponding thiol in the appropriate phosphate buffer - remained in equilibrium with air. The formation of fluorescent $\mathbf{C O H}$ was monitored using an Applied Photophysics SX20 stopped-flow spectrophotometer equipped with a fluorescence detector and a thermostatically controlled cell $\left(25^{\circ} \mathrm{C}\right)$ with a $10-\mathrm{mm}$ optical pathway. The reaction mixtures were excited at $332 \mathrm{~nm}$ and the emitted light intensity was measured at $470 \mathrm{~nm}$ (PMT voltage $=850 \mathrm{~V}$, emission/excitation slit $=2.5 \mathrm{~nm}$ ). The initial rates of the increase in the fluorescence intensity were fitted with a linear function. The data were analyzed using the Origin Pro 2015 program (OriginLab Corporation, Northampton, MA, USA).

\section{pH Determination}

The $\mathrm{pH}$ of the phosphate buffers and the exact $\mathrm{pH}$ of the solutions after mixing were measured using a SevenMulti $^{\mathrm{TM}} \mathrm{pH}$ meter (Mettler Toledo GmbH, Schwerzenbach, Switzerland).

\section{Computational Details}

Quantum mechanical calculations were performed in the Gaussian G09 suite of programs, Revision E01 [78]. The geometries of the stationary points were fully optimized using the Hartree-Fock (HF) method as well as Density Functional Theory (DFT). The functionals M06-2X [79], B2PLYP and B3LYP were used with Grimme's D3 dispersion correction, B2PLYP-D3 [80-82] and B3LYP-D3 [83, 84], respectively. A 6-311++G(2df,2p) basis set [85] was used, with the inclusion of a water solvent. Water was represented according to the IEFPCM $[86,87]$ method by a 
default polarizable continuum solvent model in Gaussian. Structure optimizations were followed by frequency calculations, in order to verify the nature of the stationary points and to obtain corresponding free energy values. We were unable to locate any transition states for the reaction between $\mathbf{C H}_{3} \mathrm{SH}$ and $\mathbf{C H}_{2} \mathbf{O}$.

\section{Results}

To examine the effect of $\mathrm{pH}$ on the reactivity of azanone toward thiols, we used the competition kinetics method previously described in the literature [3, 12]. Due to the spontaneous dimerization of azanone, donor compounds are required that decompose with the release of the HNO molecule [10]. In our study, Angeli's salt was used as the HNO donor because it decomposes with a constant rate in the $\mathrm{pH}$ range from 4 to $8.6[56,57]$. Above $\mathrm{pH} 8$, the rate of decomposition decreases [56, 57]. The low concentration of the donor compound $(3 \mu \mathrm{M})$ in the system resulted in an initial flux of HNO below $0.15 \mu \mathrm{M} / \mathrm{min}$. Therefore, the steady-state concentration of HNO was very low. In the entire considered $\mathrm{pH}$ range, the system remained in equilibrium with air. Hence, the concentration of molecular oxygen was equal to $225 \mu \mathrm{M}$ [77]. Given all the abovementioned factors, the HNO dimerization process was negligible and was not taken into account.

Azanone is a weak acid, with a $\mathrm{p} K_{a}$ value of 11.4 [1]. Therefore, released azanone exists in its protonated form in the studied $\mathrm{pH}$ range. The rate constant of the $\mathbf{H N O}$ reaction with molecular oxygen had been determined previously as equal to $(1.8 \pm 0.3) \times 10^{4} \mathrm{M}^{-1} \mathrm{~s}^{-1}$. We assume that this rate constant does not depend on the $\mathrm{pH}$ [3]. The reaction between $\mathbf{H N O}$ and $\mathbf{O}_{2}$ results in the formation of peroxynitrite $\left(\mathrm{ONOO}^{-}\right)$[3], which in aqueous solutions exists in an acid-base equilibrium with its protonated form peroxynitrous acid (ONOOH, $\left.\mathrm{p} K_{a}=6.8\right)$ [88]. In the absence of scavengers, peroxynitrite undergoes isomerization to $\mathrm{HNO}_{3}$ ( 70\%) (Reaction 12) and homolysis to ${ }^{\circ} \mathrm{OH}$ and ${ }^{\circ} \mathrm{NO}_{2}$ radicals $(\sim 30 \%)$ (Reaction 13$)$. All these radical species are highly oxidizing and nitrating agents. Its formation in the presence of the HNO donor could lead to one-electron oxidation of the donor compound, affecting the kinetics and mechanism of its decay [61]. The use of boronate probes in the system helps effectively scavenge peroxynitrite and prevent oxidation of Angeli's salt [61].

$$
\begin{aligned}
& \mathrm{ONOOH} \rightarrow \mathrm{NO}_{3}^{-}+\mathrm{H}^{+} \\
& \mathrm{ONOOH} \rightarrow \mathrm{NO}_{2}+{ }^{\circ} \mathrm{OH}
\end{aligned}
$$

The oxidation of boronate compounds by $\mathbf{O N O O}^{-}$is a direct, stoichiometric and rapid reaction $\left(k \sim 10^{5}-10^{6} \mathrm{M}^{-1} \mathrm{~s}^{-1}\right)$, leading to the formation of the corresponding phenols as major products [76, 89-93]. However, at $\mathrm{pH}$ higher than 9 boronates undergo an addition reaction with hydroxyl ions $\left(\mathbf{H O}^{-}\right)$, yielding a product unreactive toward ONOO$^{-}$[91]. Given the pH-dependence of boronates reactivity toward $\mathbf{O N O O}^{-}$and the lower release of HNO from Angeli's salt in alkaline solutions ( $\mathrm{pH}>8.6)$, our studies were performed in a limited $\mathrm{pH}$ range (6.4-8.3) [56, 57]. The probe used in our study, coumarin boronic acid (CBA), is converted by peroxynitrite to blue fluorescent 7-hydroxycoumarin $(\mathbf{C O H})$ as a major product [76]. The high reactivity of CBA toward peroxynitrite within the studied $\mathrm{pH}$ range ensures quantitative peroxynitrite scavenging in the presence of low micromolar concentrations of the studied thiols. The formation of $\mathbf{C O H}$ formation in the presence of thiols was slower than in their absence. Based on Eq. (1), we determined the ratios of the second-order rate constants of the HNO reactions with thiol and molecular oxygen for each $\mathrm{pH}$ in the range from 6.4 to 8.3.

Assuming that HNO can react with the thiolate anion $\mathbf{R S}^{-}\left(\boldsymbol{k}_{\boldsymbol{R} S^{-}}\right)$as well as with its protonated form $\mathbf{R S H}\left(\boldsymbol{k}_{\boldsymbol{R} S \boldsymbol{H}}\right)$, the observed rate constant $\left(\boldsymbol{k}_{\boldsymbol{o b s}}\right)$ can be expressed as a function of $\mathrm{pH}$, which depends on thiol $\mathrm{p} K_{a}$, and the rate constants $\boldsymbol{k}_{R S^{-}}$and $\boldsymbol{k}_{R S \boldsymbol{H}}$ :

$k_{o b s}=\frac{k_{R S^{-}} \cdot 10^{-p k_{a}}+k_{R S H} \cdot 10^{-p H}}{10^{-p k_{a}}+10^{-p H}}$

The ratio $\boldsymbol{k}_{\boldsymbol{o b s}} / \boldsymbol{k}_{\mathbf{O}_{2}}$ can be expressed in a similar way:

$k_{o b s} / k_{O_{2}}=\frac{k_{R S^{-}} \cdot 10^{-p k_{a}}+k_{R S H} \cdot 10^{-p H}}{\left(10^{-p k_{a}}+10^{-p H}\right) \cdot k_{O_{2}}}$

The $\boldsymbol{k}_{\boldsymbol{o b s}} / \boldsymbol{k}_{\mathbf{O}_{2}}$ ratios obtained for different $\mathrm{pH}$ were fitted to Eq. (3), which allowed us to estimate the rate constants of the HNO reaction with the corresponding thiol and thiolate, separately. Figure 2A shows the dependence of the $\boldsymbol{k}_{\mathbf{o b s}} / \boldsymbol{k}_{\mathbf{O}_{2}}$ ratio on $\mathrm{pH}$ for the reaction between $\mathbf{H N O}$ and glutathione. It is noticeable that the reactivity of HNO toward thiols is $\mathrm{pH}$-dependent. The $\mathrm{p} K_{a}$ value for the dissociation of the -SH group in glutathione was taken from the literature as being equal to 8.8 [94]. The best fitting was obtained assuming $\boldsymbol{k}_{\boldsymbol{R} S^{-}} / \boldsymbol{k}_{\mathbf{O}_{2}}$ equal to (2.1 \pm $0.1) \times 10^{3}$ and $\boldsymbol{k}_{\mathbf{R S H}} / \boldsymbol{k}_{\mathbf{O}_{2}}=100 \pm 10$. These results indicate that thiolate anions are much more reactive toward HNO than their protonated forms $\left(\boldsymbol{k}_{\boldsymbol{R} \boldsymbol{S}^{-}} \gg \boldsymbol{k}_{\mathrm{RSH}}\right)$. A similar observation was made for $N$-acetylcysteine (Fig. 2B). The $\mathrm{p} K_{a}$ value of the -SH group in $N$-acetylcysteine is equal to 9.5 [94] and the corresponding ratios $\boldsymbol{k}_{\boldsymbol{R S}}-\boldsymbol{k}_{\mathbf{O}_{2}}$ and $\boldsymbol{k}_{\mathrm{RSH}} /$ $\boldsymbol{k}_{\mathbf{O}_{2}}$ are equal to $(5.5 \pm 0.4) \times 10^{3}$ and $5 \pm 7$, respectively. Again, the reaction of HNO with thiolate is faster, hence favored.

We also performed analogical experiments for the two most abundant thiol proteins, bovine (BSA) and human (HSA) serum albumins. The $\mathrm{p} K_{a}$ values of these proteins 
A

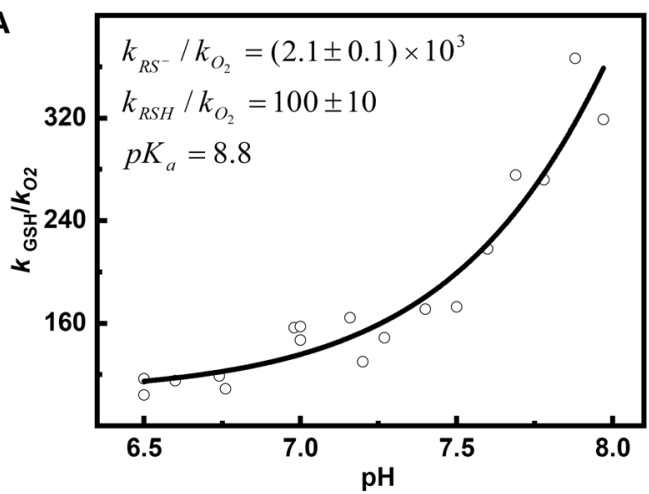

C

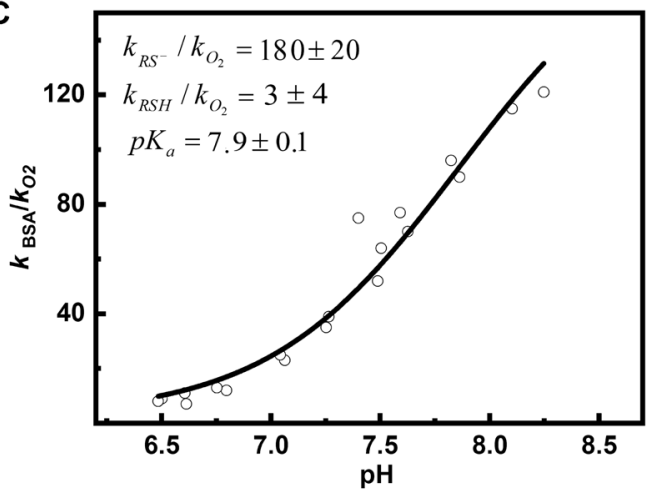

B

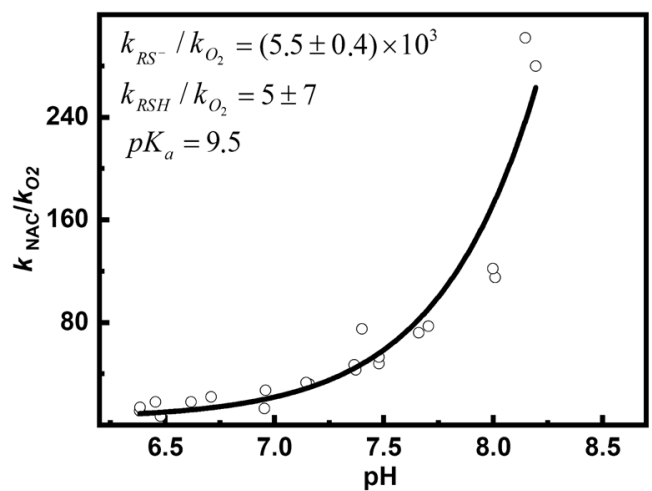

D

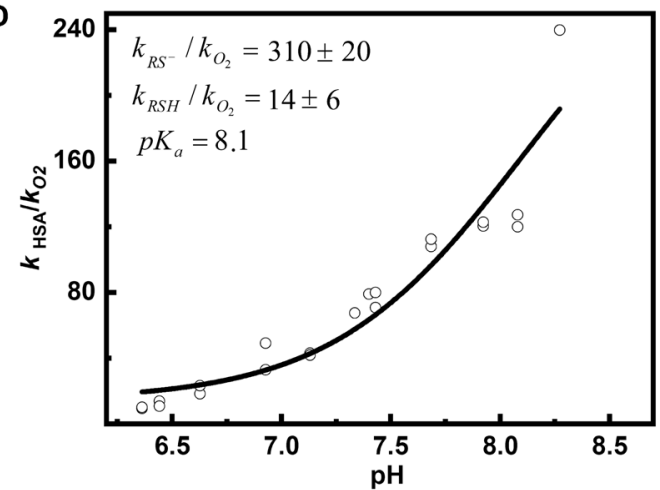

$(25 \mathrm{mM})$ at appropriate $\mathrm{pH}$ with addition of dtpa $(50 \mu \mathrm{M})$ and $5 \%$ $\mathbf{C H}_{3} \mathbf{C N}$. The solutions were excited at $332 \mathrm{~nm}$, the emitted light intensity was measured at $470 \mathrm{~nm}$ (photomultiplier voltage: $850 \mathrm{~V}$, emission/excitation slit: $2.5 \mathrm{~nm}$ )

To further examine the reaction of HNO with thiolates, we analyzed the correlation between $\boldsymbol{k}_{\mathbf{o b s}}$ and the thiolate concentration. The values for $\boldsymbol{k}_{\boldsymbol{o b s}}$ were determined based on the rate constant of the HNO reaction with molecular oxygen $\boldsymbol{k}_{\mathbf{O}_{2}}=(1.8 \pm 0.3) \times 10^{4} \mathrm{M}^{-1} \mathrm{~s}^{-1}$ [3], whereas the concentration of thiolate was calculated based on the corresponding $\mathrm{p} K_{a}$ value of the thiol. The linear relationship between $\boldsymbol{k}_{\mathbf{o b s}}$ and the thiolate concentration can be expressed by Eq. 4. The correlation is illustrated in Fig. 3.

$$
k_{o b s}=\frac{\left[R S^{-}\right]}{[S]} \cdot\left(k_{R S^{-}}-k_{R S H}\right)+k_{R S H}
$$

$2 \mathrm{D}$ shows the dependence of the $\boldsymbol{k}_{\mathbf{o b s}} \boldsymbol{k}_{\mathbf{O}_{2}}$ ratio on $\mathrm{pH}$ for the reaction between HNO and HSA. In calculations performed for HSA, we used a value for $\mathrm{p} K_{a}$ of 8.1 [101], as has been recently established by three independent approaches. The experimental data, best fitted with Eq. (3) assuming the above-mentioned $\mathrm{p} K_{a}$ value for the dissociation of the -SH group in HSA, give the ratios $\boldsymbol{k}_{\boldsymbol{R S}}-\boldsymbol{k}_{\mathrm{O}_{2}}=310 \pm 20$ and $\boldsymbol{k}_{\mathbf{R S H}} / \boldsymbol{k}_{\mathbf{O}_{2}}=14 \pm 6$. The ratio values obtained for the thiol proteins confirm the observed relationship between HNO reactivity and protonation of the sulfhydryl group in the studied compounds.
The variables $\left[\mathbf{R S}^{-}\right]$and $[\mathbf{S}]$ denote the concentration of thiolate and the total concentrations of the thiol $([\mathbf{S}]=$ $\left.[\mathbf{R S H}]+\left[\mathbf{R S}^{-}\right]\right)$, respectively, while $\mathbf{k}_{\mathbf{R S}-}$ or $\mathbf{k}_{\mathbf{R S H}}$ are the rate constants of the HNO reaction with the thiolate $\left(\mathbf{R S}^{-}\right)$ and thiol (RSH), respectively. Therefore, our approach also allows us to estimate the rate constants of the HNO reaction with the corresponding thiol and thiolate, separately. The rate constants of the HNO reaction with the appropriate thiolates is high and varies in the range $k \sim 10^{6}-10^{7} \mathrm{M}^{-1} \mathrm{~s}^{-1}$, whereas the rate constants of the HNO reaction with the 

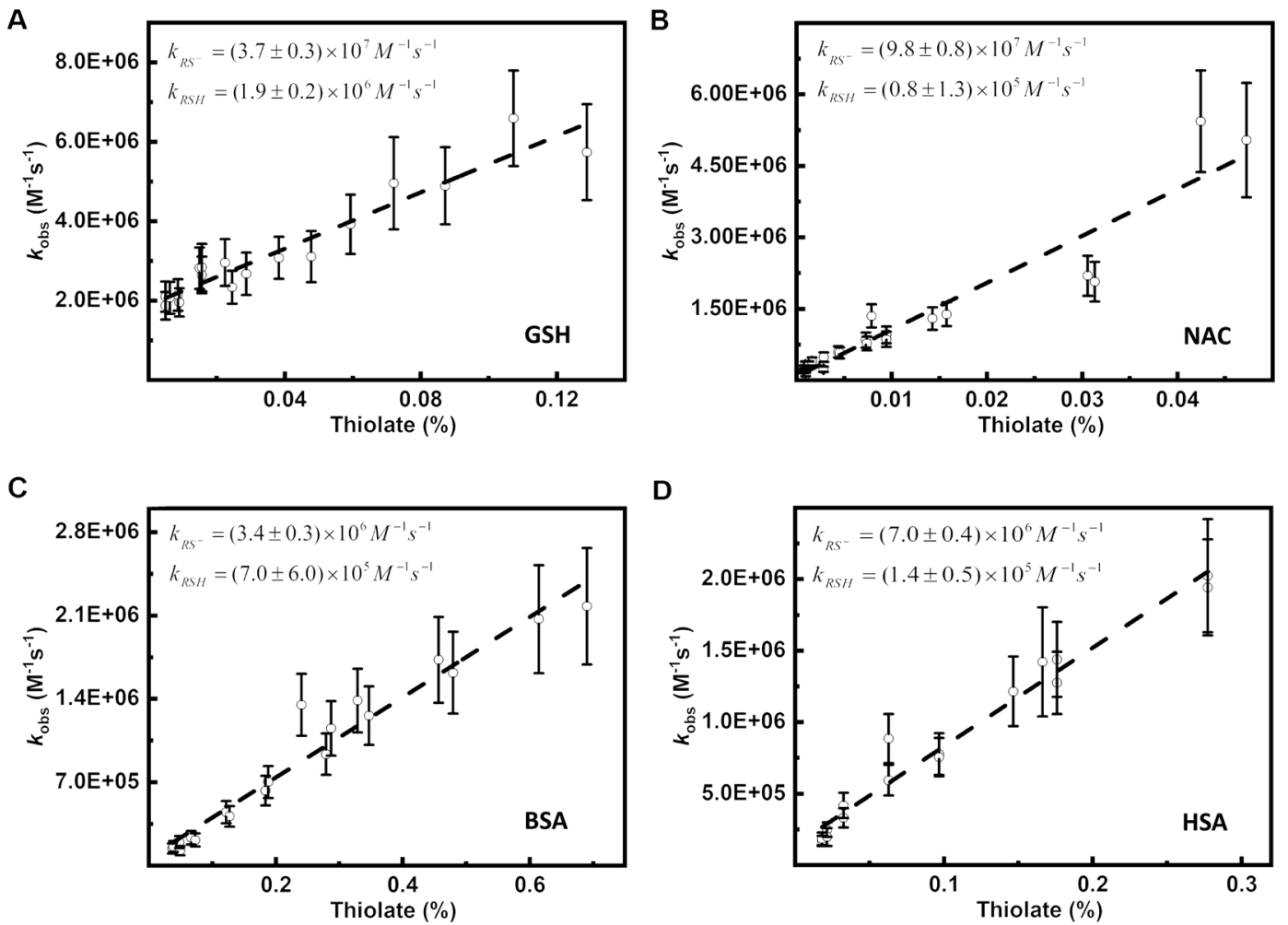

Fig. 3 Correlation between the observed rate constant $\left(\boldsymbol{k}_{\boldsymbol{o b s}}\right)$ and the deprotonated form of (A) Glutathione (GSH), B $N$-acetylcysteine (NAC), C Bovine serum albumin (BSA), D Human serum albumin (HSA). The concentration of the deprotonated form of each thiol was assessed using the appropriate $\mathrm{p} K_{\mathrm{a}}$ value: $\mathbf{A} \mathrm{p} K_{\mathrm{a}}=8.8$ [94], $\mathbf{B} \mathrm{p} K_{\mathrm{a}}=$ 9.5 [94], $\mathbf{C ~} \mathrm{p} K_{\mathrm{a}}=7.9$ (this work), $\mathbf{D} \mathrm{p} K_{\mathrm{a}}=8.1$ [101]. The appropriate $\boldsymbol{k}_{\boldsymbol{o b s}}$ was calculated from the experimentally obtained ratio $\boldsymbol{k}_{\boldsymbol{o b s}} / \boldsymbol{k}_{\mathrm{O}_{2}}$

using $\boldsymbol{k}_{\mathbf{O}_{2}}=(1.8 \pm 0.3) \times 10^{4} \mathrm{M}^{-1} \mathrm{~s}^{-1}$ [3]. Reaction mixtures consisted of $0 ; 0,5 ; 1 ; 1,5 \mu \mathrm{M}$ GSH or NAC or $0 ; 1 ; 2 ; 3 \mu \mathrm{M} \mathrm{BSA}$ or HSA, $25 \mu \mathrm{M}$ coumarin boronic acid (CBA), $3 \mu \mathrm{M}$ Angeli's salt (AS) in phosphate buffers $(25 \mathrm{mM})$ at appropriate $\mathrm{pH}$ with addition of dtpa $(50 \mu \mathrm{M})$ and $5 \% \mathbf{C H}_{3} \mathbf{C N}$. The solutions were excited at $332 \mathrm{~nm}$, the emitted light intensity was measured at $470 \mathrm{~nm}$ (photomultiplier voltage $850 \mathrm{~V}$, emission/excitation slit $2.5 \mathrm{~nm}$ )

Table 1 Comparison of the rate constants of the HNO reaction with protonated and deprotonated forms of the studied thiols based on two different approaches: (a) based on $\mathrm{pH}$ dependence of the $k_{\text {obs }}$ l $\boldsymbol{k}_{\mathrm{O}_{2}}$ ratio presented in Fig. 2; (b)

\begin{tabular}{lllll}
\hline Thiol & ${ }^{\mathrm{a}} k_{R S^{-}}\left(\mathrm{M}^{-1} \mathrm{~s}^{-1}\right)$ & ${ }^{\mathrm{a}} k_{R S H}\left(\mathrm{M}^{-1} \mathrm{~s}^{-1}\right)$ & ${ }^{\mathrm{b}} k_{R S^{-}}\left(\mathrm{M}^{-1} \mathrm{~s}^{-1}\right)$ & ${ }^{\mathrm{b}} k_{R S H}\left(\mathrm{M}^{-1} \mathrm{~s}^{-1}\right)$ \\
\hline GSH & $(3.8 \pm 0.8) \times 10^{7}$ & $(1.8 \pm 0.5) \times 10^{6}$ & $(3.8 \pm 0.3) \times 10^{7}$ & $(1.9 \pm 0.2) \times 10^{6}$ \\
NAC & $(9.9 \pm 2.4) \times 10^{7}$ & $(0.9 \pm 1.4) \times 10^{5}$ & $(9.8 \pm 0.8) \times 10^{7}$ & $(0.8 \pm 1.3) \times 10^{5}$ \\
BSA & $(3.2 \pm 0.9) \times 10^{6}$ & $(5.4 \pm 8.1) \times 10^{4}$ & $(3.4 \pm 0.3) \times 10^{6}$ & $(7.0 \pm 6.0) \times 10^{5}$ \\
HSA & $(5.6 \pm 1.3) \times 10^{6}$ & $(2.5 \pm 1.5) \times 10^{5}$ & $(7.0 \pm 0.4) \times 10^{6}$ & $(1.4 \pm 0.5) \times 10^{5}$ \\
\hline
\end{tabular}
based on the correlation between $k_{o b s}$ and the thiolate concentration of the appropriate thiol presented in Fig. 3

respective thiols is an order of magnitude lower at $k \sim 10^{5}-$ $10^{6} \mathrm{M}^{-1} \mathrm{~s}^{-1}$ (Table 1). Therefore, the same tendency can be observed: the reaction between azanone and thiolate is favored. There is a slight discrepancy between the $\boldsymbol{k}_{\mathbf{R S H}}$ values for thiol proteins computed with the aid of each approach. As can be seen in Fig. 3, the thiolate percentage is strongly dependent on the $\mathrm{p} K_{a}$ value, which according to the literature varies in the case of BSA and HSA [95-101].

To confirm our findings, quantum mechanical calculations were performed using different computational methods (Tables 2, 3). Different calculation methods for estimation of the energy barrier in the reaction of methyl thiolate $\left(\mathbf{M e S}^{-}\right)$with $\mathbf{H N O}$ give discrepant values. The relatively high energy barrier $(125 \mathrm{~kJ} / \mathrm{mol})$ was computed with ab initio HF theory, whereas DFT calculations predicted the barrier to be about $27 \mathrm{~kJ} / \mathrm{mol}$ for the M06-2X DFT functional and $13,12 \mathrm{~kJ} / \mathrm{mol}$ for the B2PLYP-D3 and B3PLYP-D3 functionals, respectively. It is worth underlining that the energy barrier calculated for the reaction of HNO with $\mathbf{M e S}^{-}$is about $130-150 \mathrm{~kJ} / \mathrm{mol}$ lower than the corresponding energy barrier estimated for the reaction of neutral reactants, i.e., HNO and MeSH. 
Table 2 Comparison of computationally evaluated Gibbs free energies $\left(\Delta \mathrm{G}^{\dot{\$}}\right)$ of the studied reactions obtained using various theoretical methods

\begin{tabular}{|c|c|c|c|c|}
\hline \multirow[t]{2}{*}{ Reaction } & \multicolumn{4}{|c|}{$\Delta \mathrm{G}^{\ddagger}(\mathrm{kJ} / \mathrm{mol})$} \\
\hline & $\mathrm{HF}$ & M06-2X & B2PLYP-D3 & B3LYP-D3 \\
\hline $\mathrm{HNO}_{+} \mathrm{MES}^{-} \rightarrow \mathrm{MeSNHO}^{-}$ & 125.0 & 26.7 & 12.7 & 11.7 \\
\hline HNO+MESH $\rightarrow$ MeSNHOH & 257.1 & 163.3 & 158.2 & 159.8 \\
\hline $\mathrm{CH}_{2} \mathrm{O}+\mathrm{MeS}^{-} \rightarrow \mathrm{MeSCH}_{2} \mathrm{O}^{-}$ & 101.4 & 29.8 & 28.0 & $-^{\mathrm{a}}$ \\
\hline $\mathrm{MeSNHO}^{-} \rightarrow \mathrm{HNO}^{+} \mathrm{MeS}^{-}$ & 45.4 & 16.6 & 3.3 & 2.1 \\
\hline MeSNHOH $\rightarrow$ HNO + MeSH & 245.5 & 204.9 & 187.4 & 187.6 \\
\hline $\mathrm{MeSCH}_{2} \mathrm{O}^{-} \rightarrow \mathrm{CH}_{2} \mathrm{O}+\mathrm{MeS}^{-}$ & 0.2 & 1.6 & 0.8 & - \\
\hline
\end{tabular}

${ }^{\mathrm{a}}$ Lack of data due to no transition state found
The $130 \mathrm{~kJ} / \mathrm{mol}$ difference was computed based on HF theory, while DFT calculations estimated the difference as about $136 \mathrm{~kJ} / \mathrm{mol}$ for the M06-2X DFT functional and $145,148 \mathrm{~kJ} / \mathrm{mol}$ for the B2PLYP-D3 and B3PLYP-D3 DFT functionals, respectively. It is interesting that even though the absolute energies computed for stationary points using DFT methods were significantly lower than the values obtained with HF, they resulted in slightly higher energy differences. Nevertheless, the qualitative outcomes of the different theoretical calculations were consistent, showing that azanone reacts faster with the thiolate. In the reverse reaction, $\sim 185-200 \mathrm{~kJ} / \mathrm{mol}$ more energy is required for MeSNHOH decomposition than for decomposition of its deprotonated form $\mathrm{MeSNHO}^{-}$into substrates, i.e., HNO and the thiolate. The calculated energy barriers for the reaction of methyl thiolate $\left(\mathbf{M e S}^{-}\right)$ with electrophilic $\mathbf{C H}_{2} \mathbf{O}$ (isoelectric with HNO) are similar in value to those calculated for the $\mathbf{M e S}^{-}$reaction with HNO (Table 2).

\section{Discussion}

The mechanism of the HNO reaction with thiols is currently understood to involve an initial nucleophilic attack of the thiol on the electrophilic nitrogen of azanone, forming $N$-hydroxysulfenamide (Reaction 1) [34, 35]. Therefore, our finding that the rate constant of the reaction of $\mathbf{H N O}$ with thiols depends on its $\mathbf{p} \boldsymbol{K}_{\mathbf{a}}$ value is not surprising. Using the presented approaches, we were able to estimate the rate constants of the HNO reaction with the corresponding thiol and thiolate separately. Supported by quantum mechanical calculations, the results indicate that azanone is much more reactive toward thiolates (RS ${ }^{-}$) than toward protonated forms of thiols (RSH). This leads to the conclusion that it is the thiolate that nucleophilically attacks the HNO double bond. This mechanism is similar to the well-established reaction mechanism of thiols with carbonyl compounds, including
$\mathbf{C H}_{\mathbf{2}} \mathbf{O}$, leading to the formation of hemithioacetals. It is commonly accepted that in these reactions the addition of thiols proceeds by the reaction of thiolate anion $\mathbf{R S}^{-}$ [102, 103].

The mechanism of the reaction between azanone and thiols may be comparable to the formaldehyde $\left(\mathbf{C H}_{\mathbf{2}} \mathbf{O}\right)$ reaction with thiols, in which formaldehyde acts as an electrophile that reacts with biological nucleophiles, including thiols [104]. By analogy, the first step of the reaction may be a nucleophilic attack by the thiolate on the $\mathbf{C H}_{2} \mathbf{O}$ double bond, leading to the formation of the $S$ hydroxymethyl adduct, an analog of $\mathrm{N}$-hydroxysulfenamide [104].

Quantum mechanical results obtained for the detachment of $\mathrm{HNO}$ from $\mathrm{MeSNHO}^{-} / \mathrm{MeSNHOH}$ can be compared with our recently published data on the decomposition of Piloty's acid ( $N$-hydroxybenzenesulfonamide, $\mathrm{C}_{6} \mathrm{H}_{5} \mathrm{SO}_{2} \mathrm{~N}$ $\mathrm{HOH})$ and its derivatives [61]. The mechanisms in the processes are quite similar. The decomposition mechanism of Piloty's acid and its derivatives include initial deprotonation of oxygen $\left(\mathrm{C}_{6} \mathrm{H}_{5} \mathrm{SO}_{2} \mathrm{NHO}^{-}\right)$and subsequent $\mathrm{S}-\mathrm{N}$ bond heterolysis, leading to slow release of the productsbenzenesulfinate and HNO [57, 61]. We hypothesize that the $\mathrm{p} K_{\mathrm{a}}$ value of RSNHOH at physiological $\mathrm{pH}$ may be high, so the protonation reaction of $\mathbf{R S N H O}^{-}$occurs spontaneously. As a consequence, the stable RSNHOH is formed.

\section{Conclusion}

The reaction of azanone with thiol proteins is one of the major factors responsible for its unique pharmacological effects. In the present study, we have demonstrated both that this reaction depends strongly on $\mathrm{pH}$ and that HNO is highly reactive toward thiolates $\left(\mathbf{R S}^{-}\right)$. These results support the currently proposed reaction mechanism of HNO with thiols, involving an initial nucleophilic attack by the thiol on the electrophilic nitrogen of azanone. 
Table 3 Comparison of calculated bond lengths and selected angles for substrates, transition states and products of the studied azanone reactions with $\mathrm{MeS}^{-}$or MeSH

\begin{tabular}{|c|c|c|c|c|c|c|}
\hline & \multicolumn{3}{|c|}{ Bond length $(\AA)$} & \multicolumn{3}{|c|}{ Angle $\left(^{\circ}\right)$} \\
\hline & C-S & S-N & $\mathrm{N}-\mathrm{O}$ & H-C-S & C-S-N & S-N-O \\
\hline \multicolumn{7}{|c|}{$\mathrm{MeS}^{-}+\mathrm{HNO}^{\rightarrow} \mathrm{MeSNHO}^{-}$} \\
\hline \multicolumn{7}{|c|}{ HNO } \\
\hline $\mathrm{HF}$ & - & - & 1.168 & & & \\
\hline M06-2X & - & - & 1.192 & & & \\
\hline B2PLYP-D3 & - & - & 1.210 & & & \\
\hline B3LYP-D3 & - & - & 1.201 & & & \\
\hline \multicolumn{7}{|l|}{$\mathbf{M e S}^{-}$} \\
\hline $\mathrm{HF}$ & 1.833 & - & - & & & \\
\hline M06-2X & 1.836 & - & - & & & \\
\hline B2PLYP-D3 & 1.842 & - & - & & & \\
\hline B3LYP-D3 & 1.849 & - & - & & & \\
\hline \multicolumn{7}{|l|}{ TS } \\
\hline $\mathrm{HF}$ & 1.808 & 2.139 & 1.261 & 110.58 & 99.35 & 111.34 \\
\hline M06-2X & 1.796 & 2.198 & 1.275 & 111.39 & 94.77 & 110.23 \\
\hline B2PLYP-D3 & 1.804 & 1.999 & 1.336 & 110.71 & 97.26 & 111.69 \\
\hline B3LYP-D3 & 1.812 & 2.017 & 1.329 & 110.56 & 98.46 & 111.99 \\
\hline \multicolumn{7}{|l|}{ MeSHNO $^{-}$} \\
\hline $\mathrm{HF}$ & 1.807 & 1.691 & 1.383 & 106.79 & 106.16 & 115.25 \\
\hline M06-2X & 1.812 & 1.726 & 1.391 & 107.77 & 104.01 & 114.19 \\
\hline B2PLYP-D3 & 1.820 & 1.749 & 1.404 & 107.62 & 104.86 & 114.54 \\
\hline B3LYP-D3 & 1.830 & 1.762 & 1.396 & 107.40 & 105.96 & 115.19 \\
\hline \multicolumn{7}{|c|}{ MeSH + HNO $\rightarrow$ MeSNHOH } \\
\hline $\mathrm{HF}$ & - & - & 1.168 & & & \\
\hline M06-2X & - & - & 1.192 & & & \\
\hline B2PLYP-D3 & - & - & 1.210 & & & \\
\hline B3LYP-D3 & - & - & 1.201 & & & \\
\hline \multicolumn{7}{|l|}{ MeSH } \\
\hline $\mathrm{HF}$ & 1.815 & - & - & & & \\
\hline M06-2X & 1.816 & - & - & & & \\
\hline B2PLYP-D3 & 1.823 & - & - & & & \\
\hline B3LYP-D3 & 1.829 & - & - & & & \\
\hline \multicolumn{7}{|l|}{ TS } \\
\hline $\mathrm{HF}$ & 1.792 & 1.686 & 1.408 & 108.36 & 102.60 & 99.08 \\
\hline M06-2X & 1.791 & 1.708 & 1.411 & 107.28 & 99.90 & 100.12 \\
\hline B2PLYP-D3 & 1.796 & 1.723 & 1.429 & 108.72 & 100.19 & 99.87 \\
\hline B3LYP-D3 & 1.805 & 1.728 & 1.427 & 108.16 & 100.67 & 99.95 \\
\hline \multicolumn{7}{|l|}{ MeSNHOH } \\
\hline $\mathrm{HF}$ & 1.805 & 1.681 & 1.385 & 105.75 & 105.37 & 115.94 \\
\hline M06-2X & 1.809 & 1.693 & 1.412 & 105.89 & 104.24 & 114.99 \\
\hline B2PLYP-D3 & 1.816 & 1.699 & 1.435 & 105.64 & 105.26 & 115.21 \\
\hline B3LYP-D3 & 1.824 & 1.702 & 1.435 & 105.45 & 106.01 & 115.84 \\
\hline
\end{tabular}

Acknowledgements The calculations mentioned in this paper were performed using Lodz University of Technology Computing \& Information Services Center infrastructure.

Author Contributions All authors contributed to the study conception and design. Material preparation, data collection and analysis were performed by R.S.-I. and K.D. Quantum-mechanical calculations were performed by M.R. Chemical synthesis was performed by J.A. The first draft of the manuscript was written by R.S.-I. and all authors commented on subsequent versions of the manuscript. All authors read and approved the final manuscript.

Funding A.S. was supported by the Polish National Science Center within the SONATA BIS program (Grant Number 2015/18/E/ST4/ 00235) and R.S.-I. was supported by grant W-3/FMN/26G/2015 from Lodz University of Technology.

\section{Compliance with Ethical Standards}

Conflict of Interest The authors declare no competing interests.

Publisher's note Springer Nature remains neutral with regard to jurisdictional claims in published maps and institutional affiliations.

Open Access This article is licensed under a Creative Commons Attribution 4.0 International License, which permits use, sharing, adaptation, distribution and reproduction in any medium or format, as long as you give appropriate credit to the original author(s) and the source, provide a link to the Creative Commons license, and indicate if changes were made. The images or other third party material in this article are included in the article's Creative Commons license, unless indicated otherwise in a credit line to the material. If material is not included in the article's Creative Commons license and your intended use is not permitted by statutory regulation or exceeds the permitted use, you will need to obtain permission directly from the copyright holder. To view a copy of this license, visit http://creativecommons. org/licenses/by/4.0/.

\section{References}

1. Shafirovich, V., \& Lymar, S. V. (2002). Nitroxyl and its anion in aqueous solutions: spin states, protic equilibria, and reactivities toward oxygen and nitric oxide. Proceedings of the National Academy of Sciences of the United States of America, 99 (11):7340-7345. https://doi.org/10.1073/pnas.112202099.

2. Venâncio, M. F., Doctorovich, F., \& Rocha, W. R. (2017). Solvation and proton-coupled electron transfer reduction potential of ${ }^{2} \mathrm{NO} \cdot$ to ${ }^{1} \mathrm{HNO}$ in aqueous solution: a theoretical investigation. The Journal of Physical Chemistry B, 121(27), 6618-6625. https://doi.org/10.1021/acs.jpcb.7b03552.

3. Smulik, R., Debski, D., Zielonka, J., Michalowski, B., Adamus, J., Marcinek, A., Kalyanaraman, B., \& Sikora, A. (2014). Nitroxyl (HNO) reacts with molecular oxygen and forms peroxynitrite at physiological $\mathrm{pH}$. Biological Implications. Journal of Biological Chemistry, 289(51), 35570-35581. https://doi.org/ 10.1074/jbc.M114.597740.

4. Miranda, K. M., Espey, M. G., Yamada, K., Krishna, M., Ludwick, N., Kim, S., Jourd'heuil, D., Grisham, M. B., Feelisch, M., Fukuto, J. M., \& Wink, D. A. (2001). Unique oxidative mechanisms for the reactive nitrogen oxide species, nitroxyl anion. Journal of Biological Chemistry, 276(3), 1720-1727. https://doi.org/10.1074/jbc.M006174200.

5. Miranda, K. M., Yamada, K., Espey, M. G., Thomas, D. D., DeGraff, W., Mitchell, J. B., Krishna, M. C., Colton, C. A., \& Wink, D. A. (2002). Further evidence for distinct reactive intermediates from nitroxyl and peroxynitrite: effects of buffer composition on the chemistry of Angeli's salt and synthetic peroxynitrite. Archives of Biochemistry and Biophysics, 401(2), 134-144. https://doi.org/10.1016/s0003-9861(02)00031-0.

6. Jorolan, J. H., Buttitta, L. A., Cheah, C., \& Miranda, K. M. (2015). Comparison of the chemical reactivity of synthetic 
peroxynitrite with that of the autoxidation products of nitroxyl or its anion. Nitric Oxide, 44, 39-46. https://doi.org/10.1016/j.niox. 2014.11.002.

7. Donald, C. E., Hughes, M. N., Thompson, J. M., \& Bonner, F. T. (1986). Photolysis of the $\mathrm{N}=\mathrm{N}$ bond in trioxodinitrate: Reaction between triplet $\mathrm{NO}^{-}$and $\mathrm{O}_{2}$ to form peroxonitrite. Inorganic Chemistry, 25, 2676-2677. https://doi.org/10.1002/chin. 198645036.

8. Kirsch, M., \& de Groot, H. (2002). Formation of peroxynitrite from reaction of nitroxyl anion with molecular oxygen. Journal of Biological Chemistry, 277(16), 13379-13388. https://doi.org/ 10.1074/jbc.M108079200.

9. Bryukov, M., Kachanov, A., Timonnen, R., Seetula, J., Vandoren, J., \& Sarkisov, O. (1993). Kinetics of HNO reactions with $\mathrm{O}_{2}$ and HNO. Chemical Physics Letters, 208(5-6), 392-398.

10. Shafirovich, V., \& Lymar, S. V. (2003). Spin-forbidden deprotonation of aqueous nitroxyl (HNO). Journal of the American Chemical Society, 125(21), 6547-6552. https://doi.org/10.1021/ ja034378j.

11. Liochev, S. I., \& Fridovich, I. (2003). The mode of decomposition of Angeli's salt $\left(\mathrm{Na}_{2} \mathrm{~N}_{2} \mathrm{O}_{3}\right)$ and the effects thereon of oxygen, nitrite, superoxide dismutase, and glutathione. Free Radical Biology and Medicine, 34(11), 1399-1404. https://doi. org/10.1016/s0891-5849(03)00111-4.

12. Smulik-Izydorczyk, R., Mesjasz, A., Gerbich, A., Adamus, J., Michalski, R., \& Sikora, A. (2017). A kinetic study on the reactivity of azanone (HNO) toward its selected scavengers: Insight into its chemistry and detection. Nitric Oxide, 69(Supplement C), 61-68. https://doi.org/10.1016/j.niox.2017.05.003.

13. Jackson, M. I., Han, T. H., Serbulea, L., Dutton, A., Ford, E., Miranda, K. M., Houk, K. N., Wink, D. A., \& Fukuto, J. M. (2009). Kinetic feasibility of nitroxyl reduction by physiological reductants and biological implications. Free Radical Biology and Medicine, 47(8), 1130-1139. https://doi.org/10.1016/j.freera dbiomed.2009.06.034.

14. Miranda KM, Paolocci N, Katori T, Thomas DD, Ford E, Bartberger MD, Espey MG, Kass DA, Feelisch M, Fukuto JM, Wink DA (2003) A biochemical rationale for the discrete behavior of nitroxyl and nitric oxide in the cardiovascular system. Proceedings of the National Academy of Sciences of the United States of America 100 (16):9196-9201. https://doi.org/10. 1073/pnas.1430507100.

15. Liochev, S. I., \& Fridovich, I. (2002). Nitroxyl (NO-): a substrate for superoxide dismutase. Archives of Biochemistry and Biophysics, 402(2), 166-171. https://doi.org/10.1016/S00039861(02)00074-7.

16. Sulc, F., Immoos, C. E., Pervitsky, D., \& Farmer, P. J. (2004). Efficient trapping of HNO by deoxymyoglobin. Journal of the American Chemical Society, 126(4), 1096-1101. https://doi.org/ 10.1021/ja0376184.

17. Kumar, M. R. \& Farmer, P. J. In: F. Doctorovich, P. J. Farmer M. A. Marti, (eds.) 2017). 14 - Spectroscopic NMR characterizations of $\mathrm{HNO}$ adducts of ferrous heme proteins. The chemistry and biology of nitroxyl (HNO). (pp. 269-285). Boston: Elsevier. https://doi.org/10.1016/B978-0-12-800934-5.00014-1.

18. Zapata, A. L., Kumar, M. R., Pervitsky, D., \& Farmer, P. J. (2013). A singular value decomposition approach for kinetic analysis of reactions of HNO with myoglobin. Journal of Inorganic Biochemistry, 118, 171-178. https://doi.org/10.1016/j. jinorgbio.2012.10.005.

19. Boron, I., Suarez, S. A., Doctorovich, F., Marti, M. A., \& Bari, S. E. (2011). A protective protein matrix improves the discrimination of nitroxyl from nitric oxide by MnIII protoporphyrinate IX in aerobic media. Journal of Inorganic Biochemistry, 105(8), 1044-1049. https://doi.org/10.1016/j. jinorgbio.2011.05.002.
20. Bari, S. E., Marti, M. A., Amorebieta, V. T., Estrin, D. A., \& Doctorovich, F. (2003). Fast nitroxyl trapping by ferric porphyrins. Journal of the American Chemical Society, 125(50), 15272-15273. https://doi.org/10.1021/ja036370f.

21. Alvarez, L., Suarez, S. A., Bikiel, D. E., Reboucas, J. S., BatinicHaberle, I., Marti, M. A., \& Doctorovich, F. (2014). Redox potential determines the reaction mechanism of HNO donors with $\mathrm{Mn}$ and $\mathrm{Fe}$ porphyrins: defining the better traps. Inorganic Chemistry, 53(14), 7351-7360. https://doi.org/10.1021/ ic5007082.

22. Marti, M. A., Bari, S. E., Estrin, D. A., \& Doctorovich, F. (2005). Discrimination of nitroxyl and nitric oxide by watersoluble Mn(III) porphyrins. Journal of the American Chemical Society, 127(13), 4680-4684. https://doi.org/10.1021/ja044632n.

23. Vaananen, A. J., Salmenpera, P., Hukkanen, M., Miranda, K. M., Harjula, A., Rauhala, P., \& Kankuri, E. (2008). Persistent susceptibility of cathepsin B to irreversible inhibition by nitroxyl (HNO) in the presence of endogenous nitric oxide. Free Radical Biology and Medicine, 45(6), 749-755. https://doi.org/10.1016/j. freeradbiomed.2008.05.025.

24. Shoeman, D. W., \& Nagasawa, H. T. (1998). The reaction of nitroxyl (HNO) with nitrosobenzene gives cupferron (N-nitrosophenylhydroxylamine). Nitric Oxide, 2(1), 66-72. https://doi. org/10.1006/niox.1998.0166.

25. Samuni, U., Samuni, Y., \& Goldstein, S. (2010). On the distinction between nitroxyl and nitric oxide using nitronyl nitroxides. Journal of the American Chemical Society, 132(24), 8428-8432. https://doi.org/10.1021/ja101945j.

26. Samuni, Y., Samuni, U., \& Goldstein, S. (2013). The use of cyclic nitroxide radicals as HNO scavengers. Journal of Inorganic Biochemistry, 118, 155-161. https://doi.org/10.1016/j. jinorgbio.2012.10.002.

27. Bobko, A. A., Ivanov, A., \& Khramtsov, V. V. (2013). Discriminative EPR detection of NO and HNO by encapsulated nitronyl nitroxides. Free Radical Research, 47(2), 74-81. https:// doi.org/10.3109/10715762.2012.746460.

28. Reisz, J. A., Klorig, E. B., Wright, M. W., \& King, S. B. (2009). Reductive phosphine-mediated ligation of nitroxyl (HNO). Organic Letters, 11(13), 2719-2721. https://doi.org/10.1021/ ol900914s.

29. Reisz, J. A., Zink, C. N., \& King, S. B. (2011). Rapid and selective nitroxyl (HNO) trapping by phosphines: kinetics and new aqueous ligations for HNO detection and quantitation. Journal of the American Chemical Society, 133(30), 11675-11685. https://doi.org/10.1021/ja203652z.

30. Miao, Z., Reisz, J. A., Mitroka, S. M., Pan, J., Xian, M., \& King, S. B. (2015). A selective phosphine-based fluorescent probe for nitroxyl in living cells. Bioorganic \& Medicinal Chemistry Letters, 25(1), 16-19. https://doi.org/10.1016/j.bmcl.2014.11.041.

31. Kawai, K., Ieda, N., Aizawa, K., Suzuki, T., Miyata, N., \& Nakagawa, H. (2013). A reductant-resistant and metal-free fluorescent probe for nitroxyl applicable to living cells. Journal of the American Chemical Society, 135(34), 12690-12696. https://doi.org/10.1021/ja404757s.

32. Mao, G. J., Zhang, X. B., Shi, X. L., Liu, H. W., Wu, Y. X., Zhou, L. Y., Tan, W., \& Yu, R. Q. (2014). A highly sensitive and reductant-resistant fluorescent probe for nitroxyl in aqueous solution and serum. Chemical Communications, 50(43), 5790-5792. https://doi.org/10.1039/c4cc01440e.

33. Jing, X., Yu, F., \& Chen, L. (2014). Visualization of nitroxyl (HNO) in vivo via a lysosome-targetable near-infrared fluorescent probe. Chemical Communications, 50(91), 14253-14256. https://doi.org/10.1039/c4cc07561g.

34. Donzelli, S., Espey, M. G., Thomas, D. D., Mancardi, D., Tocchetti, C. G., Ridnour, L. A., Paolocci, N., King, S. B., Miranda, K. M., Lazzarino, G., Fukuto, J. M., \& Wink, D. A. (2006). 
Discriminating formation of HNO from other reactive nitrogen oxide species. Free Radical Biology and Medicine, 40(6), 1056-1066. https://doi.org/10.1016/j.freeradbiomed.2005.10. 058.

35. Filipovic, M In: F. Doctorovich, P. J. Farmer M. A. Marti, (eds.) 2017). 6 - HNO-Thiol relationship. The chemistry and biology of nitroxyl (HNO). (pp. 105-126). Boston: Elsevier. 10.1016/B9780-12-800934-5.00006-2.

36. Suarez, S. A., Muñoz, M., Alvarez, L., Venâncio, M. F., Rocha, W. R., Bikiel, D. E., Marti, M. A., \& Doctorovich, F. (2017). $\mathrm{HNO}$ is produced by the reaction of $\mathrm{NO}$ with thiols. Journal of the American Chemical Society, 139(41), 14483-14487. https:// doi.org/10.1021/jacs.7b06968.

37. Wong, P. S., Hyun, J., Fukuto, J. M., Shirota, F. N., DeMaster, E. G., Shoeman, D. W., \& Nagasawa, H. T. (1998). Reaction between S-nitrosothiols and thiols: generation of nitroxyl (HNO) and subsequent chemistry. Biochemistry, 37(16), 5362-5371. https://doi.org/10.1021/bi973153g.

38. Ivanova, L. V., Cibich, D., Deye, G., Talipov, M. R., \& Timerghazin, Q. K. (2017). Modeling of S-nitrosothiol-thiol reactions of biological significance: HNO production by S-thiolation requires a proton shuttle and stabilization of polar intermediates. ChemBioChem, 18(8), 726-738. https://doi.org/10.1002/cbic. 201600556.

39. Tsikas, D., \& Bohmer, A. (2017). S-Transnitrosation reactions of hydrogen sulfide (H2S/HS(-)/S(2-)) with S-nitrosated cysteinyl thiols in phosphate buffer of $\mathrm{pH}$ 7.4: Results and review of the literature. Nitric Oxide, 65, 22-36. https://doi.org/10.1016/j.niox. 2017.02.001.

40. Kirsch, M., Buscher, A. M., Aker, S., Schulz, R. \& de Groot, H. (2009). New insights into the S-nitrosothiol-ascorbate reaction The formation of nitroxyl. Organic \& Biomolecular Chemistry, 7 (9), 1954-1962. https://doi.org/10.1039/b901046g.

41. Hamer, M., Suarez, S. A., Neuman, N. I., Alvarez, L., Muñoz, M., Marti, M. A., \& Doctorovich, F. (2015). Discussing endogenous $\mathrm{NO}^{*} / \mathrm{HNO}$ interconversion aided by phenolic drugs and vitamins. Inorganic Chemistry, 54(19), 9342-9350. https://doi. org/10.1021/acs.inorgchem.5b01347.

42. Suarez, S. A., Neuman, N. I., Muñoz, M., Álvarez, L. A., Bikiel, D. E., Brondino, C. D., Ivanović-Burmazović, I., Miljkovic, J. L., Filipovic, M. R., Martí, M. A., \& Doctorovich, F. (2015). Nitric oxide is reduced to HNO by proton-coupled nucleophilic attack by ascorbate, tyrosine, and other alcohols. A new route to HNO in biological media? Journal of the American Chemical Society, 137 (14), 4720-4727. https://doi.org/10.1021/ja512343w.

43. Pryor, W. A., Church, D. F., Govindan, C., \& Crank, G. (1982). Oxidation of thiols by nitric oxide and nitrogen dioxide: synthetic utility and toxicological implications. Journal of Organic Chemistry, 47(1), 156-159. https://doi.org/10.1021/jo00340a 038.

44. DeMaster, E. G., Quast, B. J., Redfern, B., \& Nagasawa, H. T. (1995). Reaction of nitric oxide with the free sulfhydryl group of human serum albumin yields a sulfenic acid and nitrous oxide. Biochemistry, 34(36), 11494-11499.

45. Aravindakumar, C. T., Ley, M. D., \& Ceulemans, J. (2002). Kinetics of the anaerobic reaction of nitric oxide with cysteine, glutathione and cysteine-containing proteins: implications for in vivo S-nitrosation. Journal of the Chemical Society, Perkin Transactions, 2(3), 663-669. https://doi.org/10.1039/B107273K.

46. Hogg, N., Singh, R. J., \& Kalyanaraman, B. (1996). The role of glutathione in the transport and catabolism of nitric oxide. FEBS Letters, 382(3), 223-228. https://doi.org/10.1016/0014-5793(96) 00086-5.

47. Folkes, L. K., \& Wardman, P. (2004). Kinetics of the reaction between nitric oxide and glutathione: implications for thiol depletion in cells. Free Radical Biology and Medicine, 37(4), 549-556. https://doi.org/10.1016/j.freeradbiomed.2004.05.012.

48. Vanin, A. F., Sanina, N. A., Serezhenkov, V. A., Burbaev, D., Lozinsky, V. I., \& Aldoshin, S. M. (2007). Dinitrosyl-iron complexes with thiol-containing ligands: spatial and electronic structures. Nitric Oxide, 16(1), 82-93. https://doi.org/10.1016/j. niox.2006.07.005.

49. Stojanović, S., Stanić, D., Nikolić, M., Spasić, M., \& Niketić, V. (2004). Iron catalyzed conversion of NO into nitrosonium (NO $+)$ and nitroxyl (HNO/NO-) species. Nitric Oxide, 11(3), 256-262. https://doi.org/10.1016/j.niox.2004.09.007.

50. Vanin, A. F.(2019). What is the mechanism of nitric oxide conversion into nitrosonium ions ensuring S-nitrosating processes in living organisms. Cell Biochemistry and Biophysics, 77 (4), 279-292. https://doi.org/10.1007/s12013-019-00886-1.

51. Hickok, J. R., Sahni, S., Shen, H., Arvind, A., Antoniou, C., Fung, L. W. \& Thomas, D. D. (2011). Dinitrosyliron complexes are the most abundant nitric oxide-derived cellular adduct: biological parameters of assembly and disappearance. Free Radical Biology and Medicine, 51(8), 1558-1566. https://doi.org/10. 1016/j.freeradbiomed.2011.06.030.

52. Keszler, A., Diers, A. R., Ding, Z., \& Hogg, N. (2017). Thiolatebased dinitrosyl iron complexes: Decomposition and detection and differentiation from S-nitrosothiols. Nitric Oxide, 65, 1-9. https://doi.org/10.1016/j.niox.2017.01.007.

53. Bosworth, C. A., Toledo, Jr, J. C., Zmijewski, J. W., Li, Q. \& Lancaster, Jr, J. R. (2009). Dinitrosyliron complexes and the mechanism(s) of cellular protein nitrosothiol formation from nitric oxide. Proceedings of the National Academy of Sciences of the United States of America, 106(12), 4671-4676. https://doi. org/10.1073/pnas.0710416106.

54. Tseng, Y.-T., Chen, C.-H., Lin, J.-Y., Li, B.-H., Lu, Y.-H., Lin, C.-H., Chen, H.-T., Weng, T.-C., Sokaras, D., Chen, H.-Y., Soo, Y.-L., \& Lu, T.-T. (2015). To transfer or not to transfer? Development of a dinitrosyl iron complex as a nitroxyl donor for the nitroxylation of an feiii-porphyrin center. Chemistry - A European Journal, 21(49), 17570-17573. https://doi.org/10. 1002/chem.201503176.

55. Liu, T., Zhang, M., Terry, M. H., Schroeder, H., Wilson, S. M., Power, G. G., Li, Q., Tipple, T. E., Borchardt, D. \& Blood, A. B. (2018). Hemodynamic effects of glutathione-liganded binuclear dinitrosyl iron complex: evidence for nitroxyl generation and modulation by plasma albumin. Molecular Pharmacology, 93(5), 427-437. https://doi.org/10.1124/mol.117.110957.

56. Hughes, M. N., \& Wimbledon, P. E. (1976). The chemisry of trioxodinitrates. Part I. Decompostion of sodium trioxodinitrate (Angeli's salt) in aqueous solution. Journal of the Chemical Society, Dalton Transactions, 8, 703-707. https://doi.org/10. 1039/DT9760000703.

57. Hughes, M. N., \& Cammack, R. (1999). Synthesis, chemistry, and applications of nitroxyl ion releasers sodium trioxodinitrate or Angeli's salt and Piloty's acid. Methods in Enzymology, 301, 279-287. https://doi.org/10.1016/s0076-6879(99)01092-7.

58. Cline, M. R., Tu, C., Silverman, D. N., \& Toscano, J. P. (2011). Detection of nitroxyl (HNO) by membrane inlet mass spectrometry. Free Radical Biology and Medicine, 50(10), 1274-1279. https://doi.org/10.1016/j.freeradbiomed.2011.02.008.

59. Aizawa, K., Nakagawa, H., Matsuo, K., Kawai, K., Ieda, N., Suzuki, T., \& Miyata, N. (2013). Piloty's acid derivative with improved nitroxyl-releasing characteristics. Bioorganic \& Medicinal Chemistry Letters, 23(8), 2340-2343. https://doi.org/10. 1016/j.bmcl.2013.02.062.

60. Sirsalmath, K., Suarez, S. A., Bikiel, D. E., \& Doctorovich, F. (2013). The pH of HNO donation is modulated by ring substituents in Piloty's acid derivatives: azanone donors at 
biological pH. Journal of Inorganic Biochemistry, 118, 134-139. https://doi.org/10.1016/j.jinorgbio.2012.10.008.

61. Smulik-Izydorczyk, R., Rostkowski, M., Gerbich, A., Jarmoc, D., Adamus, J., Leszczyńska, A., Michalski, R., Marcinek, A., Kramkowski, K., \& Sikora, A. (2018). Decomposition of Piloty's acid derivatives - Toward the understanding of factors controlling HNO release. Archives of Biochemistry and Biophysics. https://doi.org/10.1016/j.abb.2018.11.012.

62. Nagasawa, H. T., DeMaster, E. G., Redfern, B., Shirota, F. N., \& Goon, D. J. W. (1990). Evidence for nitroxyl in the catalasemediated bioactivation of the alcohol deterrent agent cyanamide. Journal of Medicinal Chemistry, 33(12), 3120-3122. https://doi. org/10.1021/jm00174a001.

63. DeMaster, E. G., Redfern, B., \& Nagasawa, H. T. (1998). Mechanisms of inhibition of aldehyde dehydrogenase by nitroxyl, the active metabolite of the alcohol deterrent agent cyanamide. Biochemical Pharmacology, 55(12), 2007-2015. https://doi.org/10.1016/s0006-2952(98)00080-x.

64. Paolocci, N., Jackson, M. I., Lopez, B. E., Miranda, K., Tocchetti, C. G., Wink, D. A., Hobbs, A. J., \& Fukuto, J. M. (2007). The pharmacology of nitroxyl (HNO) and its therapeutic potential: not just the Janus face of NO. Pharmacology \& Therapeutics, 113(2), 442-458. https://doi.org/10.1016/j.pha rmthera.2006.11.002.

65. Sabbah, H. N., Tocchetti, C. G., Wang, M., Daya, S., Gupta, R. C., Tunin, R. S., Mazhari, R., Takimoto, E., Paolocci, N., Cowart, D., Colucci, W. S., \& Kass, D. A. (2013). Nitroxyl (HNO): A novel approach for the acute treatment of heart failure. Circulation Heart Failure, 6(6), 1250-1258. https://doi.org/10. 1161/circheartfailure.113.000632.

66. Arcaro, A., Lembo, G., \& Tocchetti, C. G. (2014). Nitroxyl (HNO) for treatment of acute heart failure. Current Heart Failure Reports, 11(3), 227-235. https://doi.org/10.1007/s11897014-0210-z.

67. Cowart, D., Venuti, R., Guptill, J., Noveck, R., \& Foo, S. (2015). A phase 1 study of the safety and pharmacokinetics of the intravenous nitroxyl prodrug, CXL-1427. Journal of the American College of Cardiology, 65, A876 https://doi.org/10.1016/ S0735-1097(15)60876-2.

68. Tita C, Gilbert EM, Van Bakel AB, Grzybowski J, Haas GJ, Jarrah M, Dunlap SH, Gottlieb SS, Klapholz M, Patel PC, Pfister R, Seidler T, Shah KB, Zielinski T, Venuti RP, Cowart D, Foo SY, Vishnevsky A, Mitrovic V (2017) A Phase 2a doseescalation study of the safety, tolerability, pharmacokinetics and haemodynamic effects of BMS-986231 in hospitalized patients with heart failure with reduced ejection fraction. European Journal of Heart Failure. https://doi.org/10.1002/ejhf.897.

69. Norris, A. J., Sartippour, M. R., Lu, M., Park, T., Rao, J. Y., Jackson, M. I., Fukuto, J. M., \& Brooks, M. N. (2008). Nitroxyl inhibits breast tumor growth and angiogenesis. International Journal of Cancer, 122(8), 1905-1910. https://doi.org/10.1002/ ijc. 23305.

70. Basudhar, D., Cheng, R. C., Bharadwaj, G., Ridnour, L. A., Wink, D. A., \& Miranda, K. M. (2015). Chemotherapeutic potential of diazeniumdiolate-based aspirin prodrugs in breast cancer. Free Radical Biology and Medicine, 83, 101-114. https://doi.org/10.1016/j.freeradbiomed.2015.01.029.

71. Shoman, M. E., \& Aly, O. M. (2016). Nitroxyl (HNO): a possible strategy for fighting cancer. Current Topics in Medicinal Chemistry, 16(22), 2464-2470. https://doi.org/10.2174/ 1568026616666160212123006.

72. Zarpelon, A. C., Souza, G. R., Cunha, T. M., Schivo, I. R., Marchesi, M., Casagrande, R., Pinge-Filho, P., Cunha, F. Q., Ferreira, S. H., Miranda, K. M., \& Verri, Jr, W. A. (2013). The nitroxyl donor, Angeli's salt, inhibits inflammatory hyperalgesia in rats. Neuropharmacology, 71, 1-9. https://doi.org/10.1016/j. neuropharm.2013.03.009.

73. Staurengo-Ferrari, L., Zarpelon, A. C., Longhi-Balbinot, D. T., Marchesi, M., Cunha, T. M., Alves-Filho, J. C., Cunha, F. Q., Ferreira, S. H., Casagrande, R., Miranda, K. M., \& Verri, W. A. (2014). Nitroxyl inhibits overt pain-like behavior in mice: Role of cGMP/PKG/ATP-sensitive potassium channel signaling pathway. Pharmacological Reports, 66(4), 691-698. https://doi. org/10.1016/j.pharep.2014.04.003.

74. Keceli, G., Majumdar, A., Thorpe, C. N., Jun, S., Tocchetti, C. G., Lee, D. I., Mahaney, J. E., Paolocci, N. \& Toscano, J. P. (2019). Nitroxyl (HNO) targets phospholamban cysteines 41 and 46 to enhance cardiac function. Journal of General Physiology, 151(6), 758-770. https://doi.org/10.1085/jgp.201812208.

75. Mundina-Weilenmann, C. B. \& Mattiazzi, A. (2019). Tracking nitroxyl-derived posttranslational modifications of phospholamban in cardiac myocytes. Journal of General Physiology, 151 (6), 718-721. https://doi.org/10.1085/jgp.201912342.

76. Zielonka, J., Sikora, A., Joseph, J., \& Kalyanaraman, B. (2010). Peroxynitrite is the major species formed from different flux ratios of co-generated nitric oxide and superoxide: direct reaction with boronate-based fluorescent probe. Journal of Biological Chemistry, 285(19), 14210-14216. https://doi.org/10.1074/jbc. M110.110080.

77. Beckman, J. S., \& Koppenol, W. H. (1996). Nitric oxide, superoxide, and peroxynitrite: the good, the bad, and ugly. American Journal of Physiology, 271(5 Pt 1), C1424-C1437. https://doi.org/10.1152/ajpcell.1996.271.5.C1424.

78. M. J. Frisch GWT, H. B. Schlegel, G. E. Scuseria, M. A. Robb, J. R. Cheeseman, G. Scalmani, V. Barone, G. A. Petersson, H. Nakatsuji, X. Li, M. Caricato, A. Marenich, J. Bloino, B. G. Janesko, R. Gomperts, B. Mennucci, H. P. Hratchian, J. V. Ortiz, A. F. Izmaylov, J. L. Sonnenberg, D. Williams-Young, F. Ding, F. Lipparini, F. Egidi, J. Goings, B. Peng, A. Petrone, T. Henderson, D. Ranasinghe, V. G. Zakrzewski, J. Gao, N. Rega, G. Zheng, W. Liang, M. Hada, M. Ehara, K. Toyota, R. Fukuda, J. Hasegawa, M. Ishida, T. Nakajima, Y. Honda, O. Kitao, H. Nakai, T. Vreven, K. Throssell, J. A. Montgomery, Jr, J. E. Peralta, F. Ogliaro, M. Bearpark, J. J. Heyd, E. Brothers, K. N. Kudin, V. N. Staroverov, T. Keith, R. Kobayashi, J. Normand, K. Raghavachari, A. Rendell, J. C. Burant, S. S. Iyengar, J. Tomasi, M. Cossi, J. M. Millam, M. Klene, C. Adamo, R. Cammi, J. W. Ochterski, R. L. Martin, K. Morokuma, O. Farkas, J. B. Foresman, and D. J. Fox Gaussian 09 Rev. E.01, Wallingford, CT, 2016.

79. Zhao, Y., \& Truhlar, D. G. (2008). The M06 suite of density functionals for main group thermochemistry, thermochemical kinetics, noncovalent interactions, excited states, and transition elements: two new functionals and systematic testing of four M06-class functionals and 12 other functionals. Theoretical Chemistry Accounts, 120(1), 215-241. https://doi.org/10.1007/ s00214-007-0310-x.

80. Grimme, S., Antony, J., Ehrlich, S., \& Krieg, H. (2010). A consistent and accurate ab initio parametrization of density functional dispersion correction (DFT-D) for the 94 elements H$\mathrm{Pu}$. The Journal of Chemical Physics, 132(15), 154104 https:// doi.org/10.1063/1.3382344.

81. Grimme, S., Ehrlich, S., \& Goerigk, L. (2011). Effect of the damping function in dispersion corrected density functional theory. Journal of Computational Chemistry, 32(7), 1456-1465. https://doi.org/10.1002/jcc. 21759.

82. Goerigk, L., \& Grimme, S. (2011). efficient and accurate doublehybrid-meta-GGA density functionals-Evaluation with the extended GMTKN30 database for general main group thermochemistry, kinetics, and noncovalent interactions. Journal of 
Chemical Theory and Computation, 7(2), 291-309. https://doi. org/10.1021/ct100466k.

83. Becke, A. D. (1992). Density-functional thermochemistry. I. The effect of the exchange-only gradient correction. The Journal of Chemical Physics, 96(3), 2155-2160. https://doi.org/10.1063/1. 462066.

84. Stephens, P. J., Devlin, F. J., Chabalowski, C. F., \& Frisch, M. J. (1994). Ab Initio Calculation of Vibrational Absorption and Circular Dichroism Spectra Using Density Functional Force Fields. The Journal of Physical Chemistry, 98(45), 11623-11627. https://doi.org/10.1021/j100096a001.

85. Wiberg, K. B. (1986). Ab Initio Molecular Orbital Theory by W. J. Hehre, L. Radom, P. v. R. Schleyer, and J. A. Pople, John Wiley, New York, 548pp. Price: \$79.95. (1986). Journal of Computational Chemistry, 7(3), 379-379. https://doi.org/10. $1002 / j c c .540070314$.

86. Miertuš, S., Scrocco, E., \& Tomasi, J. (1981). Electrostatic interaction of a solute with a continuum. A direct utilizaion of $\mathrm{AB}$ initio molecular potentials for the prevision of solvent effects. Chemical Physics, 55(1), 117-129. https://doi.org/10. 1016/0301-0104(81)85090-2.

87. Pascual-ahuir, J. L., Silla, E., \& Tuñon, I. (1994). GEPOL: An improved description of molecular surfaces. III. A new algorithm for the computation of a solvent-excluding surface. Journal of Computational Chemistry, 15(10), 1127-1138. https://doi.org/ $10.1002 / j$ jc. 540151009.

88. Ferrer-Sueta, G., Campolo, N., Trujillo, M., Bartesaghi, S., Carballal, S., Romero, N., Alvarez, B., \& Radi, R. (2018). Biochemistry of peroxynitrite and protein tyrosine nitration. Chemical Reviews, 118(3), 1338-1408. https://doi.org/10.1021/a cs.chemrev.7b00568.

89. Sikora, A., Zielonka, J., Lopez, M., Joseph, J., \& Kalyanaraman, B. (2009). Direct oxidation of boronates by peroxynitrite: mechanism and implications in fluorescence imaging of peroxynitrite. Free Radical Biology and Medicine, 47(10), 1401-1407. https://doi.org/10.1016/j.freeradbiomed.2009.08.006.

90. Sikora, A., Zielonka, J., Adamus, J., Debski, D., Dybala-Defratyka, A., Michalowski, B., Joseph, J., Hartley, R. C., Murphy, M. P., \& Kalyanaraman, B. (2013). Reaction between peroxynitrite and triphenylphosphonium-substituted arylboronic acid isomers: identification of diagnostic marker products and biological implications. Chemical Research in Toxicology, 26(6), 856-867. https://doi.org/10.1021/tx300499c.

91. Dębowska, K., Dębski, D., Michałowski, B., Dybala-Defratyka, A., Wójcik, T., Michalski, R., Jakubowska, M., Selmi, A., Smulik, R., Piotrowski, Ł., Adamus, J., Marcinek, A., Chlopicki, S., \& Sikora, A. (2016). Characterization of fluorescein-based monoboronate probe and its application to the detection of peroxynitrite in endothelial cells treated with doxorubicin. Chemical Research in Toxicology, 29(5), 735-746. https://doi.org/10. 1021/acs.chemrestox.5b00431.

92. Zielonka, J., Podsiadly, R., Zielonka, M., Hardy, M. \& Kalyanaraman, B. (2016). On the use of peroxy-caged luciferin (PCL1) probe for bioluminescent detection of inflammatory oxidants in vitro and in vivo - Identification of reaction intermediates and oxidant-specific minor products. Free Radical Biology and
Medicine, 99, 32-42. https://doi.org/10.1016/j.freeradbiomed. 2016.07.023.

93. Rios, N., Piacenza, L., Trujillo, M., Martínez, A., Demicheli, V., Prolo, C., Álvarez, M. N., López, G. V., \& Radi, R. (2016). Sensitive detection and estimation of cell-derived peroxynitrite fluxes using fluorescein-boronate. Free Radical Biology and Medicine, 101, 284-295. https://doi.org/10.1016/j.freera dbiomed.2016.08.033.

94. Winterbourn, C. C., \& Metodiewa, D. (1999). Reactivity of biologically important thiol compounds with superoxide and hydrogen peroxide. Free Radical Biology and Medicine, 27(3-4), 322-328. https://doi.org/10.1016/S0891-5849(99)00051-9.

95. Radi, R., Beckman, J. S., Bush, K. M., \& Freeman, B. A. (1991). Peroxynitrite oxidation of sulfhydryls. The cytotoxic potential of superoxide and nitric oxide. Journal of Biological Chemistry, 266(7), 4244-4250.

96. Pedersen, A. O., \& Jacobsen, J. (1980). Reactivity of the thiol group in human and bovine albumin at $\mathrm{pH} 3-9$, as measured by exchange with 2, 2'-dithiodipyridine. European Journal of Biochemistry, 106(1), 291-295. https://doi.org/10.1111/j.14321033.1980.tb06022.x.

97. Alvarez, B., Ferrer-Sueta, G., Freeman, B. A., \& Radi, R. (1999). Kinetics of peroxynitrite reaction with amino acids and human serum albumin. Journal of Biological Chemistry, 274(2), 842-848. https://doi.org/10.1074/jbc.274.2.842.

98. Tong, G. C., Cornwell, W. K. \& Means, G. E. (2004). Reactions of acrylamide with glutathione and serum albumin. Toxicology Letters, 147(2), 127-131. https://doi.org/10.1016/j.toxlet.2003. 10.021.

99. Stewart, A. J., Blindauer, C. A., Berezenko, S., Sleep, D., Tooth, D., \& Sadler, P. J. (2005). Role of Tyr84 in controlling the reactivity of Cys34 of human albumin. FEBS Journal, 272(2), 353-362. https://doi.org/10.1111/j.1742-4658.2004.04474.x.

100. Spiga, O., Summa, D., Cirri, S., Bernini, A., Venditti, V., De Chiara, M., Priora, R., Frosali, S., Margaritis, A., Di Giuseppe, D., Di Simplicio, P., \& Niccolai, N. (2011). A structurally driven analysis of thiol reactivity in mammalian albumins. Biopolymers, 95(4), 278-285. https://doi.org/10.1002/bip.21577.

101. Bonanata, J., Turell, L., Antmann, L., Ferrer-Sueta, G., Botasini, S., Mendez, E., Alvarez, B. \& Coitino, E. L. (2017). The thiol of human serum albumin: Acidity, microenvironment and mechanistic insights on its oxidation to sulfenic acid. Free Radical Biology and Medicine, 108, 952-962. https://doi.org/10. 1016/j.freeradbiomed.2017.04.021.

102. Gilbert, H. F., \& Jencks, W. P. (1977). Mechanisms for enforced general acid catalysis of the addition of thiol anions to acetaldehyde. Journal of the American Chemical Society, 99(24), 7931-7947. https://doi.org/10.1021/ja00466a029.

103. Lienhard, G. E. \& Jencks, W. P. (1966). Thiol addition to the carbonyl group. Equilibria and kinetics. Journal of the American Chemical Society, 88(17), 3982-3994. https://doi.org/10.1021/ja $00969 \mathrm{a} 017$.

104. Kamps, J. J. A. G., Hopkinson, R. J., Schofield, C. J., \& Claridge, T. D. W. (2019). How formaldehyde reacts with amino acids. Communications Chemistry, 2(1), 126 https://doi.org/10. 1038/s42004-019-0224-2. 